\title{
PARTICIPATION METHODS IN THE SMART CITY CONCEPT
}

\author{
Aleksandra CZUPRYNA-NOWAK \\ Silesian University of Technology, aleksandra.nowak@polsl.pl, ORCID: 0000-0001-8565-1029
}

Purpose: Smart City is currently the most crucial ideology of urban development. To develop cities and their inhabitants, a constant dialogue between city authorities and residents is necessary. For the discussion to be possible, methods should be developed, enabling residents to talk with the city authorities. The aim of the article is to review the practices of participation of local authorities and city dwellers.

Design/methodology/approach: The article is based on an analysis of research results published in national and world publications.

Findings: Methods of participation between city authorities and residents are essential methods of communication between city authorities and residents. By communicating, residents with city authorities can work out new directions for city development. In the concept of smart city, it is crucial and essential that residents decide about the fate of their places of residence.

Originality/value: The work is theoretical. However, it is an excellent introduction to further scientific research towards the recognition of methods of participation and their application in Polish reality.

Keywords: smart cities, intelligent living conditions, smart people, methods of participation.

Category of the paper: Research paper.

\section{Introduction}

The migration of the population that has taken place in recent times in Poland has caused the expansion of cities. Urban development seems to be the natural course of things. The more so because as an artificial creation of man, the city has a chance to develop new ideas, ventures, and innovative technologies (Sikora, 2013). At the level of urban development, there is talk of the concept of Smart City, i.e., smart cities in which life and development of the population are better and more straightforward. Currently, a smart city is used interchangeably with the names: digital city, a sustainable city which indicates the direction of transformation that cities are currently undergoing. The concept of Smart City is based on six pillars: intelligent economy, 
intelligent environment, smart people, intelligent governance, mobility, and quality of life. The condition for urban development is the harmony of smart city elements (Pasternak, 2014).

The development of the smart city concept is a history of several years. In 2015, an approach based on the creative involvement of residents, i.e., the Smart City 3.0 model, appeared in the views on smart city. According to the Smart City 3.0 model, cities must be open to the active attitude of residents in creating their development. Therefore, the role of the authorities is to create conditions that actively use the creativity of the inhabitants-above all, encouraging residents to use modern technologies and to create their technological solutions.

A necessary condition for the active participation of residents in urban development seems to be appropriate methods of communication and activation of residents - methods of involvement. The purpose of the article is to review the practices of participation between residents and the authorities used in Poland and the world.

\section{Definition and idea of a smart city}

There are many definitions of a smart city in the literature. They differ in the distribution of accents between the approach to technology, city functionality, and social issues. N. Komninos claims that the smart city is an area consisting of four main elements (Komninos, 2008): the population implementing activities using knowledge or a group of such activities; digital spaces of e-services and online knowledge management tools, active institutions and procedures for creating the experience and the ability to innovate and solve problems that appear for the first time.

It is safest to give a definition that covers all of the ingredients listed. The definition presented by the Committee of Digital and Knowledge-based Cities in 2012: A smart city is "a city that uses information and communication technologies to increase the interactivity and efficiency of urban infrastructure and its components, as well as to raise the awareness of residents."

The problematic nature of the elements that make up every modern city makes it a complex socio-economic system. The development of this complex system depends mainly on the relationships that occur between the components. Advanced information and communication technologies - ICT plays a significant and essential role in the modern city - the use of ICT results primarily in reducing costs.

Six dimensions of a smart city are indicated:

- smart economy - economy using innovative solutions, based primarily on the use of production factors based on knowledge;

- smart living - high quality of life, meaning a safe experience in a city with a rich cultural and housing offer, ensuring broad access to ICT infrastructure; 
- smart people - knowledge-based societies, learners, often they are the initiators of changes taking place in the city;

- intelligent management, i.e., control based on cooperation and cooperation between users, developed procedures require the collaboration of local authorities and other city users, and above all modern technologies are used in the functioning of the city;

- intelligent mobility - a smart transport and communication system using advanced technologies to use infrastructure;

- intelligent environment - using renewable energy sources, reducing carbon dioxide emissions to the atmosphere through the use of advanced technologies, and broadly understood ecological education.

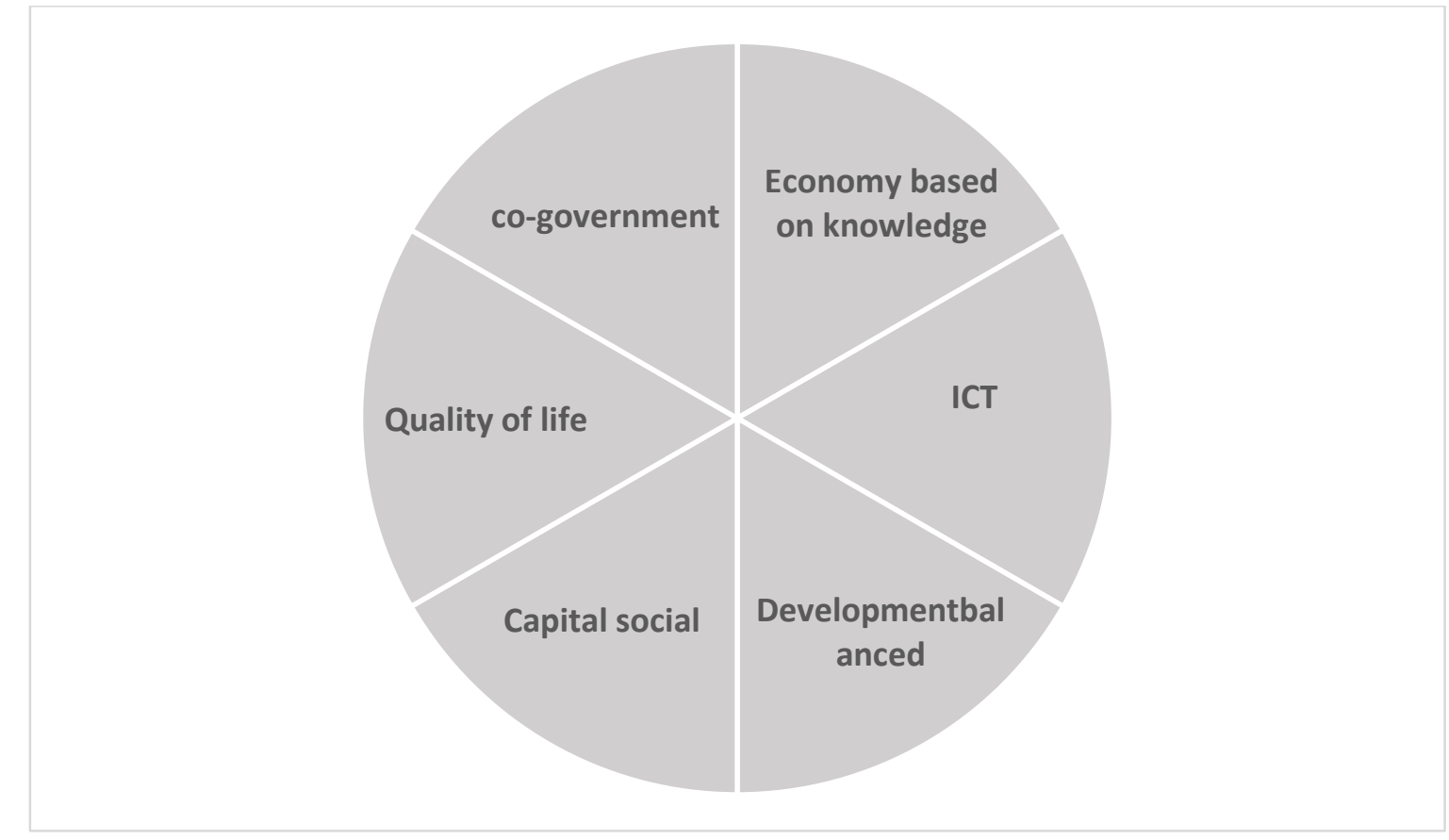

Figure 1. Components of smart city. Source: Sikora-Fernandez, 2013.

The main goals for the development of smart cities are (Otrębalski, 2019):

- ensuring higher availability and quality of public services,

- efficient city management,

- friendly living environment,

- high level of intelligence of urban infrastructure,

- dynamic and innovative economy.

\section{Cities of Smart Cities in Poland}

The development of smart cities in the world is very dynamic, and there are more and more cities boasting as Smart Cities. However, it is challenging to determine when a city is a city of 
Smart Cities and when it is not. However, we can rely on various rankings prepared by consulting companies.

The 2017 Smart Cities City Ranking - The 2017 Smart Cities Index, published by EasyPark Group, included 100 cities in the world in 2017. When assessing cities, the following factors were taken into account: the availability of high-speed $4 \mathrm{G}$ internet, the level of smartphone use in various areas of city life, transport, mobility, systems used in road traffic, and the availability of digital services in administrative matters. Of the 500 cities studied, 100 were selected. The smartest Cities, according to the ranking, were Copenhagen, Singapore, and Stockholm. One Polish city was included in the ranking: Warsaw.

In 2007, a ranking of European Smart Cities was created as part of the European Smart Cities project. As part of the project, 1,600 European cities were examined. Initially, only cities with between 100,000 and 500,000 inhabitants were studied (2007, 2013, and 2014 editions). In 2015, a map of Smart Cities was created for cities with 300,000 to 1 million inhabitants. The smart cities mentioned here are Polish cities: Szczecin, Wrocław, Gdańsk, Bydgoszcz, Poznań, Łódź, Kraków, and Lublin. Figure 1 presents a map of smart cities in Europe.

Lublin is the first city that has obtained the Certificate of Managing City Services and Quality of Life. Following PN-ISO 37120: 2015-03, Lublin received this certificate in 2019. The ISO standard assumed the assessment of the city according to indicators: indicators on the economy, education, energy, environment, finance, response to fire and other threats, administration, health, recreation, safety, shelter, solid waste, telecommunications and innovation, transport, spatial planning, wastewater and water, and sanitation.

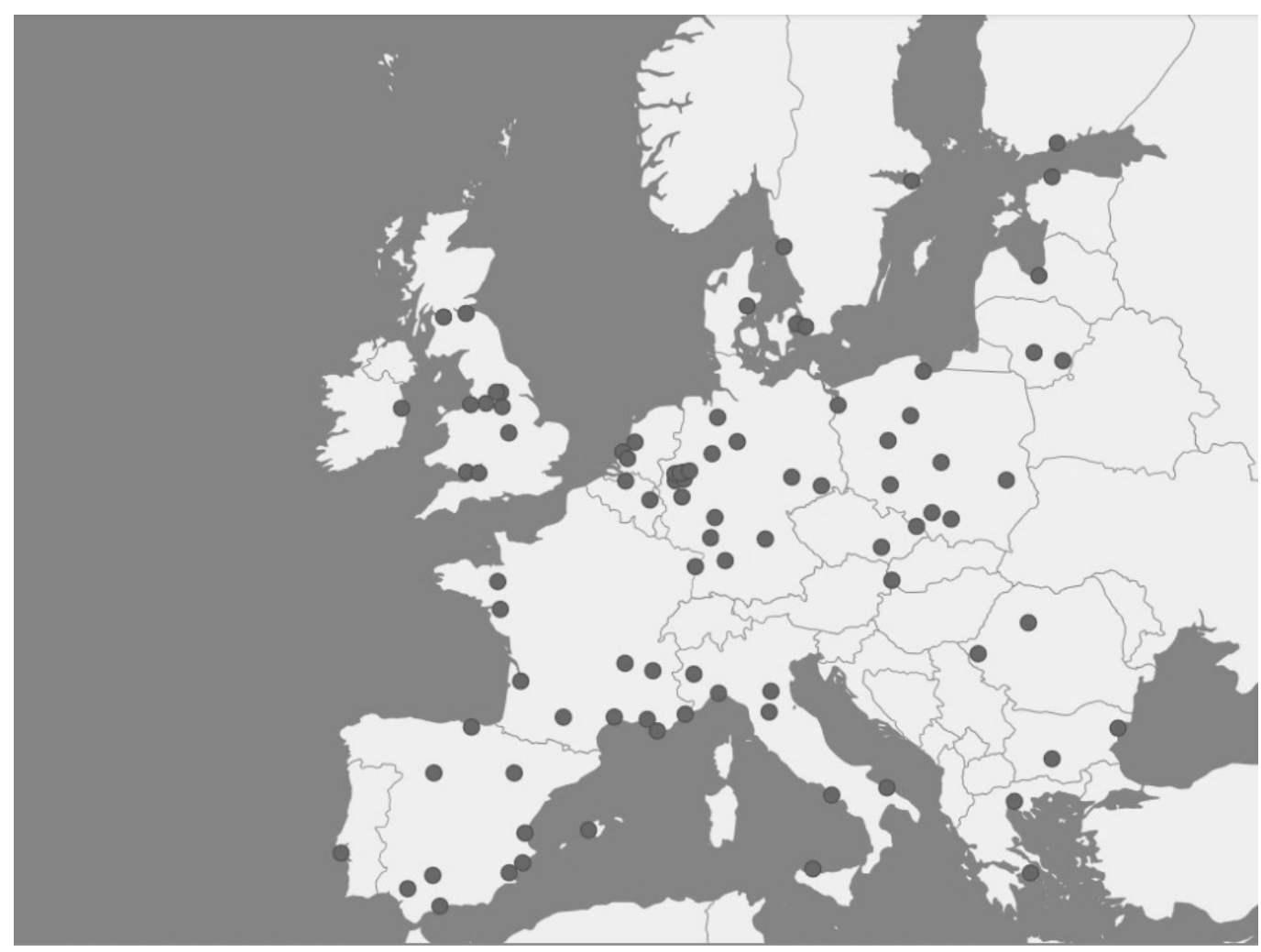

Figure 2. Smart Cities in Europe. Source: own research. 


\section{Methods of participation of residents with city authorities}

Focusing considerations related to intelligent living conditions, one should focus primarily on three dimensions: education, health, and safety of residents. K. Gotlibowska has selected a set of indicators that should be taken into account when talking about the quality of life in a smart city (Gotlibowska, 2018). However, the more important issue seems to be the conditions that the city should meet to stimulate the residents' initiative (so-called public participation).

The problem of participation has been the subject of many scientific publications: A. Urbanik (Urbanik, 2012), Ł. Prykowski (Prykowski, 2012), M. Olejnik (Olejnik, 2013) and B. Matyjaszczyk (Matyjaszczyk, 2011). These are just some publications dealing with the problem of participation in Poland. It is crucial that a partnership between local government units and residents meets certain conditions. In the process of involvement, local authorities and residents must be aware of the need for continuous dialogue. It requires from both local authorities and residents to be open to learning the participation process. Science should develop attitudes conducive to discussion and proper dialogue. Gaining experience and learning from it seems to be the most appropriate way. In Polish reality, it seems necessary to build mutual trust between local governments and the population. It requires local authorities to be focused on hearing residents' suggestions, opinions, and assessments.

It is also essential for residents to be convinced that their proposals have been taken seriously and examined. If the residents' suggestions have not found recognition, then it is the responsibility of the local government to give a fair opinion. It is also essential that communication between residents and the authorities is conducted in the appropriate language, appropriate communication channels, is adapted to the age of the recipients, and, most importantly, should not exclude disabled people. Communication in cities should be strengthened by auxiliary units - district councils, which can be an intermediate link between residents and the authorities.

The most popular instrument of public participation is participatory budgets, which in Poland have become one of the most advanced methods of residents' involvement in urban development issues. Sopot organized the first participatory budget in 2011. In 2018, regulations on the civic budget were added to the Act on municipal, commune, county, and voivodship governments, which will be applicable from the 2018-2023 term (Journal of Laws 2018, item 130). In a participatory budget, it is essential for it to activate the creativity and ingenuity of as many inhabitants as possible. It should be noted that at the same time, the participatory budget should be characterized by economy and purposefulness in spending public funds. The report published in April 2019 shows that in Polish cities, the popularity of the participatory budget increases year by year. This is mainly manifested in the number of applications submitted. In the report on participatory budget in Polish cities: Warsaw, Krakow, Łódź, Wrocław, Poznań 
and Gdańsk, the number of proposed projects increases, while the number of people voting decreases (Report 2019).

Another participative initiative is the civic resolution initiative, which allows residents to come forward with the action of draft city council resolutions. This initiative seems to be one of the essential participatory initiatives. First of all, it increases the residents' responsibility for their place of residence. It also allows you to learn about the legal conditions of the city's operation. This right was used, among others, by the inhabitants of Warsaw in the case of registration and transmission of the Wola district council and construction of a hospital in Białołęka.

An initiative that is very important for civic participation is broadly understood public consultations - also as e-consultations. Public meetings, i.e., a way of obtaining opinions and proposals from residents who are directly or indirectly affected by the effects of the proposed activities by the local government. The purpose of the consultation is to collect opinions, learn about the needs and perspectives of the residents. They do not give residents influence over the decision but are only a method of obtaining information. However, they are more than just informing citizens about planned activities. They can be carried out by traditional means as well as using various types of IT and communication tools - i.e., an on-line survey.

Access to public information is also a form of participation. Residents have the right to general information under the Act on access to public information. The act requires public authorities to disclose all information about civil matters, except classified information. Everyone has the right to obtain information without giving reasons. The Act provides broad possibilities of getting public information, including processed information, access to official documentation, and access to collegiate meetings of public authorities coming from general elections. Unfortunately, the authorities do not always respect the right of citizens to access public information.

For this reason, a Non-Governmental Center for Access to Public Information was created in Poland, run by the Civic Network Association - Watchdog Polska, which safeguards the right to information. When the right to information is not respected, the association conducts legal cases. In this way, people find out what should be the standard of implementation work about access to information, and public institutions learn the transparency of information.

Studio walks that allow you to experience the space directly are another crucial technique for both residents and institutions. Study walks can not only be used to consult specific projects but can also be an opportunity to get to know the community and their problems.

Workshop meetings using three-dimensional models are entirely different. The method engages residents at the very beginning of urban planning projects. Reviewing 3D models, residents introduce changes, suggest innovative solutions for projects prepared by city authorities. 


\section{Conclusions}

The concept of Smart Cities is becoming very popular and necessary in the operation of cities around the world. Smart Cities seems an abstract idea - it refers to areas that have already been defined but not yet fully explored. Smart Cities assumes a significant role of residents in creating the city's development. It is crucial, however, for city authorities to cooperate with residents on an ongoing basis. To this end, the city should develop various types of participatory techniques for this dialogue. In Polish reality, cities that boast of being Smart Cities use a whole range of participatory techniques. It is essential that these methods are selected appropriately to be able to build residents' confidence in local authorities. Local authorities should use a whole range of participatory techniques so that, on the one hand, they thoroughly get to know the opinions of their inhabitants, on the other, to maintain contact with as many residents as possible. It is also essential that the range of participatory techniques should be chosen differently for each city. Experience, the current level of trust in power, level of education of residents are just some of the factors that should be taken into account when choosing participatory techniques. It seems that further research should oscillate around factors that will influence the selection of participatory methods for specific cities.

\section{References}

1. AGARD (1988). Motion cues in flight simulation and simulator induced sickness (AGARD Conference Proceedings, No. 433). Neuilly Sur Seine, France: Advisory Group.

2. Caragliu, A., Del Bo, Ch., Nijkamp, P. (2008). Smart cities in Europe. Journal of Urban Technology, Vol. 18, No. 2.

3. Czupich, M., Ignasiak-Szulc, A., Kola-Bezka, M. (2016). Czynniki i bariery wdrażania koncepcji smart city w Polsce. Zeszyty Naukowe Uniwersytetu Ekopnomicznego. Studia Ekonomiczne, $n r$ 276. Katowice.

4. EasyPark Group: The 2017 Smart Cities Index. https://dkflato8y5dsg.cloudfront.net/uplo ads/5/82/s afe-cities-index-2017-eng.pdf, 02.02.2019.

5. Fazlagić, J., Jak wykorzystać koncepcję Smart Cities oraz pokrewna Smart Specialization do wsparcia rozwoju mniejszych miast w Polsce? https://www.nist.gov.pl/files/zalacznik /1467019559_Ekspertyza_01(2016)Jak_wyk_konc_SC_mix.pdf, 21.03.2019.

6. Fazlagić, J., Możliwości adaptacji rozwiąań z zakresu Smart Cities na potrzeby polskich misat? https://www.nist.gov.pl/files/zalacznik/1467019474_Ekspertyza_02(2016)Mozliw osci_adaptacji\%20_SC_mix2pdf.pdf, 21.03.2019. 
7. Florczak, W. (2011). W kierunku endogenicznego i zrównoważonego rozwoju perspektywa makroekonomiczna. Łódź: Wydawnictwo Uniwersytetu Łódzkiego.

8. Gotlibowska, K. (2018). Propozycja modelu miasta inteligentnego (Smart City) opartego na zastosowaniu technologii informacyjno-komunikacyjnych w jego rozwoju. Rozwój Regionalny i Polityka Regionalna, 42, p. 67-80.

9. Komninos, N. (2008). Intelligent Cities and Globalisationof Innovation Networks. London and New York: Routledge.

10. Li Xiaofeng, Song Junde (2014). The Top Design Methodology of Smart City in China. Intelligent Computation Technology and Automation (ICICTA) 2014 7th International Conference on, pp. 861-864.

11. Lombardi, P., Giordano, S., Farouh, H., Yousef, W. (2012). Modelling the smart city performance. Innovation - The European Journal of Social Science Research, Vol. 25, No. 2.

12. Majer, A. (2010). Socjologia i przestrzeń miejska. Warszawa: PWN.

13. Matyjaszczyk, B. (2011). Jednostki pomocnicze gminy-analiza uwarunkowań prawnych. Fundacja Pracownia Badań i Innowacji Społecznych „Stocznia”.

14. Mitchell, W. (2007). Intelligent cities. e-Journal on the Knowledge Society.

15. Obrębalski, M., Specjalizacja I inteligencja miasta - identyfikacja, pomiar i ocena. http://journals.pan.pl/Content/97930/mainfile.pdf?handler=pdf, 10.04.2019.

16. Ogorkiewicz, A.M. (2014). Polityka inteligentnych miast na szczeblu europejskim. Smart Grids Polska, $n r 2$.

17. Olejnik, M. (2013). Jak młodzi programowali dom kultury. Ewaluacja projektu partycypacyjnego $w$ praktyce.

18. Pasternak, Ł., Sadowski, A. (2014). Bariery i ograniczenia w logistyce miejskiej. Studia miejskie, tom 15.

19. Portal Urzędu Miasta Korbia, www.korbia.pl, 14.03.2019.

20. Prykowski, Ł. (2012). Głos łodzian się liczy - czyli doświadczenia z budżetem obywatelskim $w$ radach osiedli. Centrum Rozwoju i Promocji Inicjatyw Obywatelskich OPUS.

21. Raport Budzet partycypacyjny w polskich miastach. http://www.miasto2077.p1/wpcontent/uploads/2019/03/Raport-Budżety-Obywatelskie-w-polskich-miastach.pdf, 14.04.2019.

22. Sadowski, A., Koncepcja sustainability $w$ kontekście zmian zachodzacych $w$ logistyce miejskiej.

23. Sikora-Fernandez, D. (2013). Koncepcja "Smart City" w założeniach polityki rozwoju miasta - Polska perspektywa. Acta Universitatis Lodziensis. Folia Oeconomica, 290.

24. Stawasz, D., Sikora-Fernandez, D. (2014). Koncepcja smart city na tle procesów i uwarunkowań rozwoju współczesnych miast. Łódź: Wydawnictwo Uniwersytetu Łódzkiego, 
Mapping Smart Cities in the EU (2014), European Parliament IP/A/ITRE/ST/201302.2016.

25. Stawasz, D., Sikora-Fernandez, D., Turała, M. (2012). Koncepcja Smart City jako wyznacznik podejmowania decyzji związanych z funkcjonowaniem i rozwojem miasta. Studia Informatica, nr 29, Zeszyty Naukowe Uniwersytetu Szczecińskiego, nr 721.

26. Urbanik, A., Luber, J., Chrzanowski, O., Krzemińska, A. (2012). Elementy partycypacji. Fundacja Inicjatyw Społeczno-Ekonomicznych.

27. Wiśniewska, J., Janasz, K. (2012). Innowacyjność organizacji w strategii inteligentnego i zrównoważonego rozwoju. Warszawa: Difin. 